\title{
Fault Related Stress and Fractures Analysis using the Anisotropy Signatures from Azimuthal Amplitude Variation in Lematang Trend, South Sumatera Basin
}

\author{
Abdullah Nurhasan ${ }^{1, *}$, Dadang Ramdan ${ }^{1}$, Zuardino Azzaino ${ }^{1}$, Alexis Badai Samudra ${ }^{1}$, \\ and Rino Saputra ${ }^{2}$ \\ ${ }^{1}$ Pertamina EP \\ ${ }^{2}$ CGG Services Indonesia \\ *Email: abdullah.nurhasan@pertamina.com
}

Submit: 2020-11-23; Revised: 2020-11-26; Accepted: 2020-12-14

\begin{abstract}
Naturally fractured reservoir characterization relies on the knowledge of fractures orientation and current maximum horizontal stress for optimal well placement and orientation. The stress information, however, is often provided either only from a global stress map (large scale) or from well information (small scale). When well data is minimal, seismic data can act as such bridge providing useful attribute in a field scale. The presence of fracture and stress in a rock may induce anisotropy behavior in the earth (or reservoir). On the seismic scale, anisotropy of a media can be observed by looking at the different amplitude and travel time against the variation of azimuthal direction. In this sense, fracture detection is possible by observing the anisotropy signatures that seismically observable. This method utilizes seismic pre-stack data beyond the AVO and EEI method. The analysis of amplitude variation against azimuth or commonly called AVAz is conducted to infer the presence of fracture and their orientation within Lematang trend in South Sumatra, particularly in the Talang Akar Formation and Basement interval. OVT method is used during the PSTM process to preserve the information of azimuth. Seismic anisotropy magnitude and orientation is used to evaluate the orientation of fractures and current maximum horizontal stress. The result shows that local fractures and horizontal stress do vary locally and do not always follow the regional/global trend. This study provides valuable information of drilling sweet spot in a prospect with naturally fractured reservoir as its main objective.
\end{abstract}

Keywords: Anisotropy, AVAz, Fracture, South Sumatera Basin.

\begin{abstract}
Abstrak: Evaluasi reservoir terkekarkan harus didasari pengetahuan tentang arah rekahan dan stress horizontal yang dominan berlaku pada area studi. Hal ini penting untuk memberikan rekomendasi arah pengeboran yang optimal. Namun demikian, banyak informasi tentang stress yang ditemukan hanya pada skala regional, global, atau pun skala sumuran. Dalam hal pemodelan pada skala reservoir, data seismik dapat dijadikan penghubung kedua skala yang berjauhan tersebut. Rekahan dan stress yang terjadi pada
\end{abstract}

batuan dapat menyebabkan karakter anisotropi pada reservoir. Pada skala seismik, sifat anisotropi suatu media dapat diamati dari perubahan amplitudo dan waktu tempuh terhadap azimuth rambat dan pantulan gelombang seismik. Pada studi ini, kami memanfaatkan data seismil pre-stack untuk mengamati perubahan amplitudo terhadap azimuth (AVAZ). Metode ini lebih kompleks dibanding Amplitude Versus Offset (AVO) dan Extended Elastic Impedance (EEI) yang masih mengandalkan perubahan amplitude terhadap sudut pantul (atau offset). Kami memproses data seismic 3D dengan menggunakan metode Offset Vector Tile (OVT) sehingga informasi azimuth tersimpan dengan baik. Informasi yang digunakan untuk menginterpretasi orientasi rekahan dan stress horizontal maksimum adalah orientasi dan magnitudo anisotropi. Hasil studi ini menunjukkan rekahan dan stress yang bersifat local dapat dengan yang bersifat regional dan global. Hal ini menunjukkan bahwa arah pengeboran optimal tidak harus dikontrol oleh arah stress global. Kata kunci: Anisotropi, AVAZ, Reservoir Terkekarkan, Cekungan Sumatra Selatan

\section{INTRODUCTION}

South Sumatera Basin covers the area around $1.117 .000 \mathrm{~km}^{2}$ that surrounded by Barisan mountains in Southwest and Sunda Shelf in the Northeast. According to Pulunggono, Haryo, and Kosuma (1992), South Sumatera basin is divided into three phases of main tectonic events (Figure 1A). The first phase is compressional that occurred from late Jurassic to early Cretaceous that triggered by subduction of Indian Ocean to Eurasia continental plate. The subduction event generated the simple shear path in south Sumatera basin that extended to strike slip fault. The second phase (late cretaceous - early tertiary) is the extensional phase due to the decrease of subduction movement and as the result, horst and graben were created. The last phase is compressional phase (middle Miocene - recent) whereas the subduction movement started to increase that generate reverse fault.

As the tectonics activities have been quite active, understanding and mapping the existing faults and fractures in 


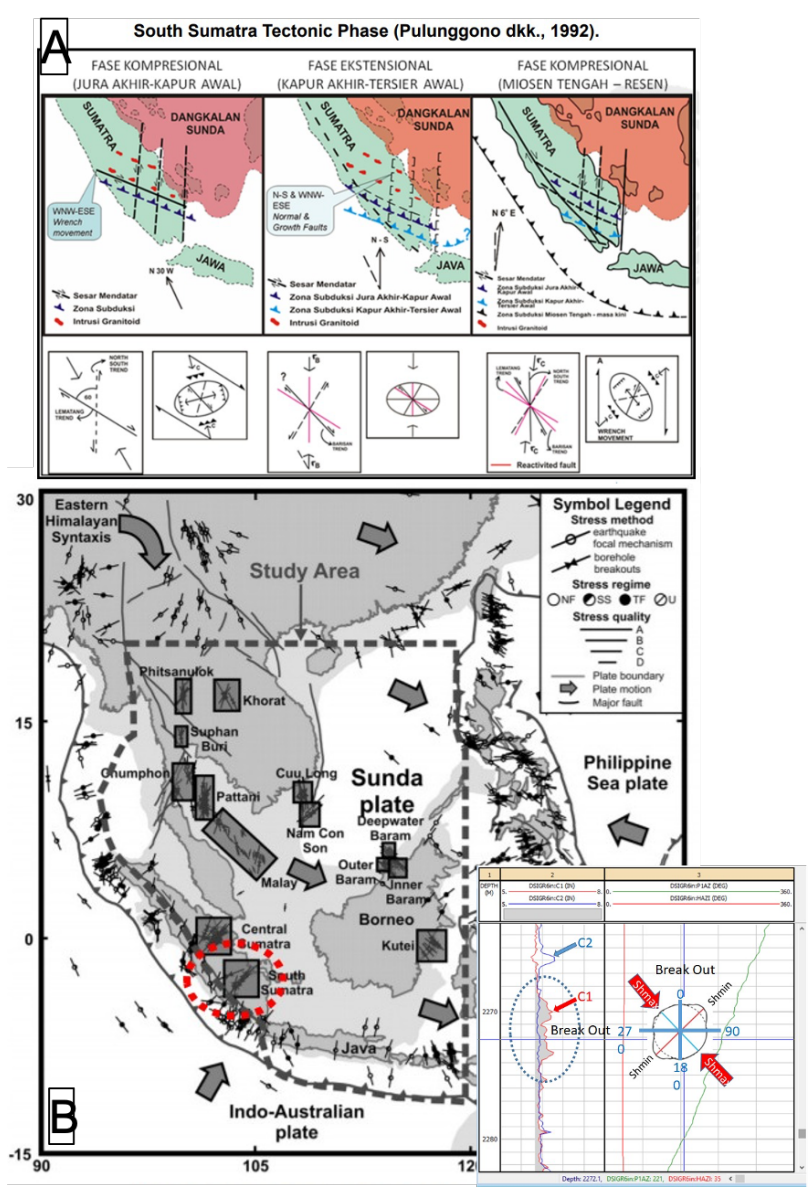

Figure 1. (A) The Three phases of main tectonic events in South Sumatera basin (Pulunggono et al., 1992).(B) Today Stress Map (Tingay et al., 2010) vs Local Stress from Wellbore Breakout

that area play critical roles. Figure $1 \mathrm{~B}$ refers to the regional stress map in Southeast Asia (Tingay et al., 2010). It shows that the dominant horizontal stress in South Sumatra is oriented to Northeast. However, many well data from various hydrocarbon field show that local stress might be oriented perpendicular to the regional stress direction. One of this finding is at our sample well located in one of the highs along Lematang Trend, which shows a maximum horizontal stress (from the wellbore breakout evaluation) orienting Northwest. We hypothesize that the local stress causing wellbore breakout might be dominantly affected by the nearby faulting regime rather than regional stress. At this point, mapping faults and fractures relies on reliable seismic data for providing faulting trend at a field scale.

The discontinuity or coherency attribute derived from post-stack seismic have been commonly used to delineate the presence of faults/fracture at the seismic scales. However, many of the small faults or fractures do not cause discontinuity (or displacement) on seismic data. In this study, we use seismic anisotropy signatures in seismic azimuthal data to evaluate the orientation of fractures and current maximum horizontal stress. The result shows that local fractures and horizontal stress do vary locally and do not always follow the regional/global trend. This study provides a valuable information of drilling sweet spot in a prospect that have

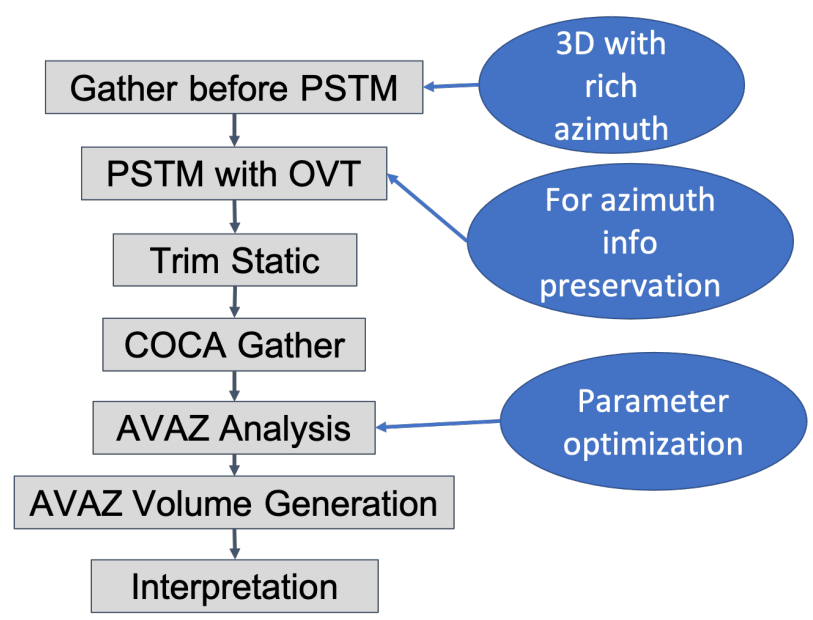

Figure 2. The workflow used in analyzing the amplitude variation with azimuth

naturally fractured reservoir as its main objective. This interpretation can complement the structural geology analysis.

\section{DATA AND METHODOLOGY}

Wang, Montagner, Fichtner, and Capdeville (2013) explained that anisotropy can exists at all scales and may be due to number of reasons such as intrinsic anisotropy, fine layers, fracture induced anisotropy, and stress induced anisotropy. In this study, we only focus on the study of analyzing the anisotropy at the scale of seismic signal. We can have the relation of anisotropy and fracture according to the seismic wave velocity that propagates through the fractured media. If seismic wave propagates in parallel direction to the fractures, it can reach higher velocity compared to seismic wave that propagate perpendicular to fractures.

The evaluation of the anisotropic signatures on seismic data requires azimuth rich $3 \mathrm{D}$ acquisition. On marine seismic, it might manifest as multi-azimuth acquisition. On land seismic, the data needs to have representative number of traces in every azimuth sector the interpreter desire to evaluate. There is no rule of thumbs of the required number of azimuth sector. However, Rüger (2002) used 4 azimuth sectors $(0,30,60,90$ degree) to model his amplitude versus azimuth reflectivity variation. The data for this study is used as input for PSTM process with OVT that also preserving the azimuth information. Trace regularization for OVT migration is done using trave borrowing method. An empty tile is allowed to borrow some traces from the neighboring tile. In this process, we limit the distance for neighboring tile to only 1 . Therefore, there might be still empty tile or azimuth/offset bin after the migration. The full workflow in this study is shown in Figure 2. The workflow covers the alignment using Trim Static as part of preconditioning data, then continued to transform OVT gather to Common Offset Common Azimuth (COCA) gather, AVAZ analysis, AVO volume generation, and interpretation of the result. The interpretation of AVAZ analysis is combined with the poststack discontinuity attribute to have better understanding of the result. 


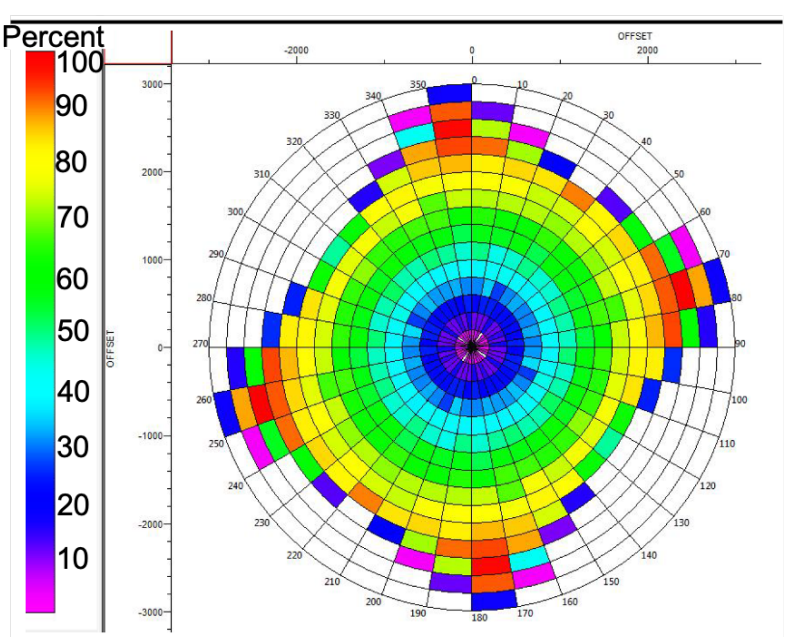

Figure 3. Offset and azimuth distribution of 3D Ginaya seismic survey.

\subsection{Data Processing and Preconditioning}

The azimuth-rich 3D seismic data we analyzed was acquired in 2009 with area around $552 \mathrm{~km} 2$. The nearest offset this survey is 520 meters while the maximum offset is 2892 meters. The distribution of offset and azimuth shown in Figure 3 depicts that the richest azimuth is at offset 2000 meters. Therefore, the AVAZ analysis will be limited to that range. Offset Vector Tile method is used during the PSTM to preserve the azimuth information. The output of the PSTM with OVT is shown in Figure 4 with the inserted rose diagram showing the richness of the azimuth (bottom left). The rose diagram shows at this particular CDP that the azimuth distribution at the near offset is not as good as the longer offset. The pre-stack data also shows that at near offset (angle) the data at the level of interest $(700 \mathrm{~ms})$ is not as good as the far offset. As the reservoir target is at the shallow level, at offset equals 1200 meters the angle of incident is equal to 40 degrees. At offset 2000 meter, the incident angle is equal to 60 degree. At greater angle, the effects of azimuthal anisotropy will be more prominent as has been modeled by Nurhasan (2017).

It is not easy to visualize both offset and azimuth dimensions at once. By that reason, the use of common offset and common azimuth display is used to see the azimuthal variations easily for both velocity analysis versus azimuth (VVAz) and amplitude analysis versus azimuth (AVAz). The basic principle of Common Offset Common Azimuth (COCA) gather display is to sort the trace by offset and then sort it by azimuth on the same section as depicted in Figure 4 (right side). The display incorporates displaying subsets of increasing azimuth within increasing offset panel which is quite ideal to detect the effect of anisotropy. It is using $\mathrm{N}$ x N spatial rolling window that we can increase the fold to ensure the data is well sampled in both offset and azimuth. That rolling mix can help to improve the signal-tonoise ratio. The COCA gathers highlight the missing traces from the near offset and the interpreter (or analyst) must take caution in in which range the AVAZ analysis is conducted.

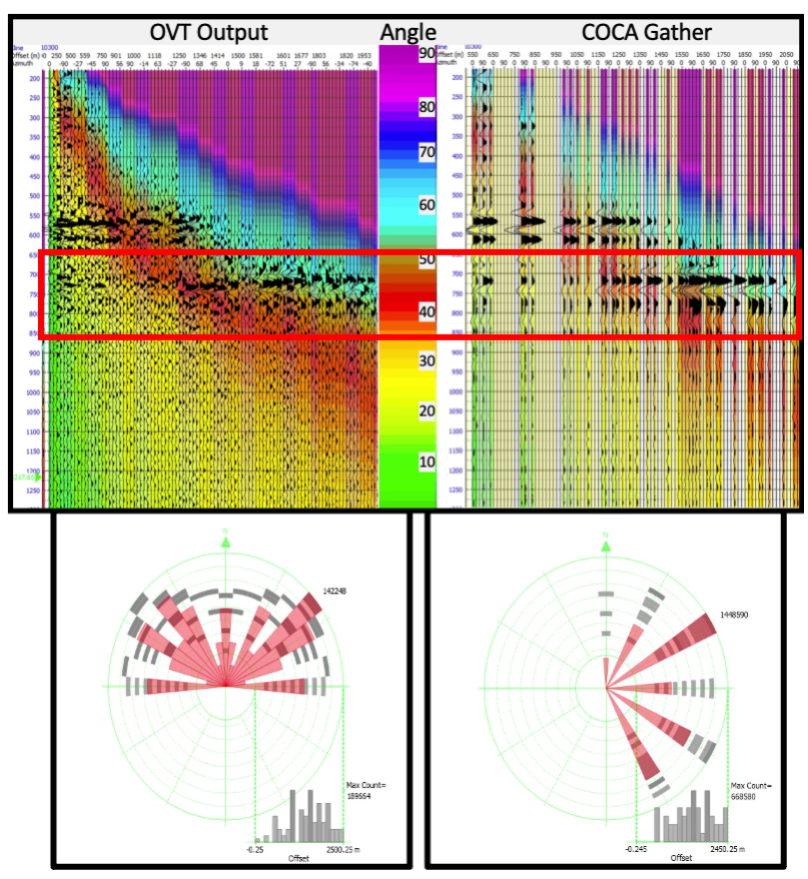

Figure 4. The Common Offset Common Azimuth display (Above) with each rose diagram showing trace (data) richness for every offset and azimuth bin. Area of interest in marked by red rectangle.

\subsection{Amplitude Analysis against Offset and Azimuth}

Amplitude of seismic wave signal can vary due to many reasons. In seismic exploration, the most common methodology to do analysis of amplitude is to observe the amplitude variation versus offset. The commonly used equation is using linearization of Zoeppritz equation such as Aki-Richards, Fatti, and so forth. For isotropic media, the first order approximation angle dependent reflection coefficient is given by equation (1), where Biso represents isotropic gradient that the value depends upon the changes in density, $\mathrm{P}$-wave velocity, and and S-wave velocity.

$$
R(\theta)=A+B_{\text {iso }} \sin ^{2} \theta
$$

In the case that we recorded data in different azimuth, the AVO relation also changes as function of azimuth as the velocity also changes. The approximation of gradient can be written as in equation (2), where $B_{a n i}$ is the term for anisotropic gradient and $\phi_{i s o}$ is the fracture strike azimuth. When the source-receiver azimuth $\phi$ is identical to $\phi_{i s o}$,

$$
R(\theta)=A+\left(B_{\text {iso }}+B_{a n i} \sin ^{2}\left(\phi-\phi_{i s o}\right)\right) \sin ^{2} \theta
$$

The extension of Zeoppritz equation in anisotropic media can be found on first paper on AVO in transversely isotropic media by Daley and Hron (1979), for orthorhombic anisotropy extended by Schoenberg and Protázio (1992), and writing the anisotropic Zoeppritz equation as Fourier series by Ikelle (1996). Thomsen (1993) modified the AkiRichards equation using his weak anisotropic parameters $(\delta$ and $\epsilon$ ) in VTI media. Rüger (2002) modified the original Thomsen's equation. For HTI media, Rüger (1998) lin- 


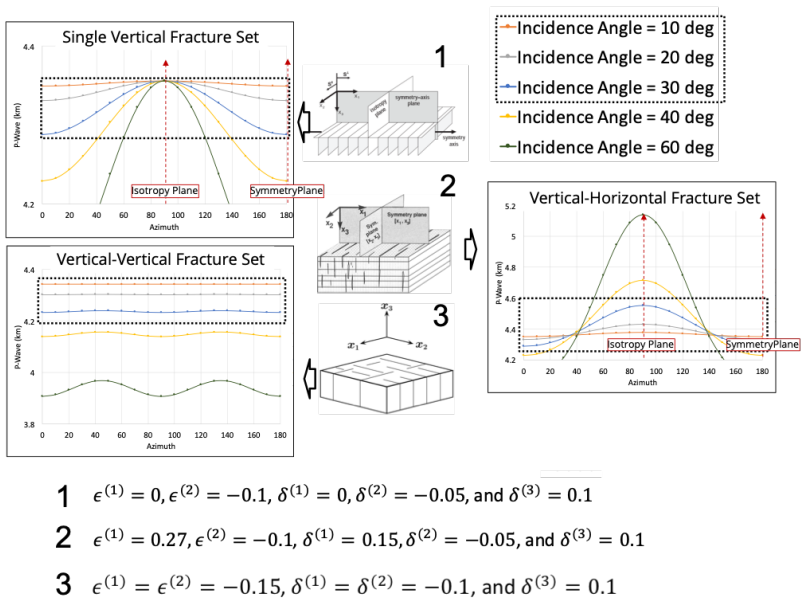

Figure 5. Model used by Nurhasan (2017) to simulate the reflectivity model using a medium anisotropic parameter. Dotted box shows the range of angle that seismic data usually consist. Anisotropy parameter for each model is listed.

earized the Zoeppritz equation for the case of an isotropic half-space over an HTI half-space. Nurhasan (2017) then adopted Rüger (1998) approximation and modified it to model the reflectivity on the orthorhombic media (Equation 3)

$$
\begin{aligned}
R_{P}^{O R T H O}(\theta, \phi)= & \frac{1}{2} \frac{\Delta Z}{\bar{Z}} \\
& +\frac{1}{2}\left\{\frac{\Delta V_{P 0}}{\overline{V_{P 0}}}-\left(\frac{2 \overline{V_{S}}}{\overline{V_{P 0}}}\right)^{2}\left(\frac{\Delta G}{\bar{G}}-2 \Delta \gamma \cos ^{2} \phi\right)\right. \\
& +\Delta \delta(\phi)\} \sin ^{2} \theta \\
& +\frac{1}{2}\left\{\frac{\Delta V_{P 0}}{\overline{V_{P 0}}}+\Delta \epsilon(\phi)\right\} \sin ^{2} \theta \tan ^{2} \theta
\end{aligned}
$$$$
\Delta \delta(\phi)=\Delta \delta^{(1)} \sin ^{2} \phi+\Delta \delta^{(2)} \cos ^{2} \phi
$$

$$
\Delta \epsilon(\phi)=\Delta \epsilon^{(1)} \sin ^{4} \phi+\Delta \epsilon^{(2)} \cos ^{4} \phi+\Delta \delta^{(2)} \sin ^{2} \phi \cos ^{2} \phi
$$

Nurhasan (2017) used the same terminology as Rüger (1998) for the P-wave $(\epsilon), \mathrm{Vp} / \mathrm{Vs}(\delta)$, and shear wave splitting $(\gamma)$ anisotropic parameter. In equation 4 and 5 , we can see that Nurhasan (2017) used $2(\epsilon)$ and $(\delta)$ for each horizontal axis (isotropy and symmetry plane), the slight modification he made for Ruger HTI reflectivity formula where he only used $\epsilon$ for the symmetry plane.

\section{MODELING}

We adopted Nurhasan (2017) model and parameter to get a prior on what we might see in the data. Unlike previous researchers such as Tsvankin (2012) and Rüger (1998) who modeled their equation with a mild anisotropy parameter, Nurhasan (2017) accommodates a medium level of anisotropy. In Figure 4, the top model represents an HTI media, which reflectivity model shows variation in the angle and azimuth domain. However, no change in amplitude

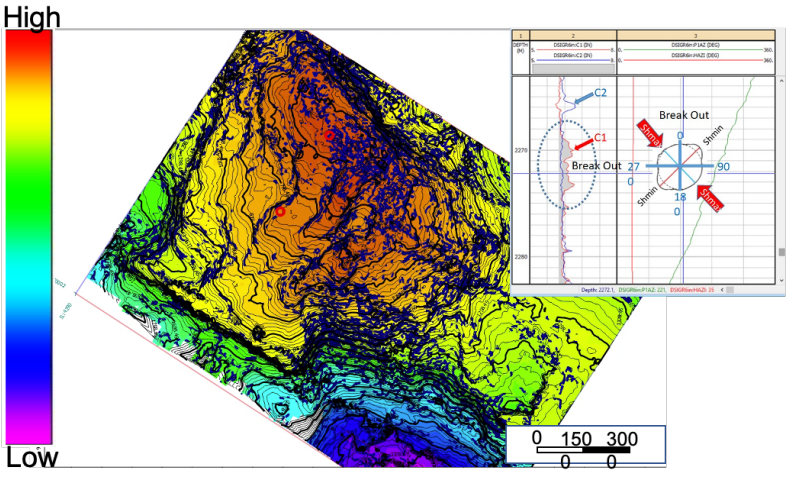

Figure 6. The time structure map overlaid with discontinuity attribute and breakout example one of the well.

with angle in the isotropy plane. The middle model shows an orthorhombic media, which purpose is to mimic the VTI effect from rock layers and HTI effect from the vertical fractures. The bottom model can also be called orthorhombic media but consist of two sets of vertical fractures. In this case the reflectivity model shows a mild amplitude variation with azimuth.

\section{RESULTS AND DISCUSSION}

The dominant fault orientation in this survey has NortheastSouthwest direction that also has similar direction of maximum horizontal stress in South Sumatera. In contrast, some wells that have been drilled indicates that the local stress might be oriented perpendicular to the regional stress direction. It can be seen in Figure 6 that displaying the time structure map that overlaid with discontinuity attribute. One of sample well located in one of the highs along Lematang Trend shows a maximum horizontal stress (from the wellbore breakout evaluation) orienting Northwest. The red circle on the map indicates the location of AVAZ analysis conducted in this study.

The result of processing stage is the OVT gather that have irregular traces in different offset and azimuth. The OVT gathers then transformed to Common Offset Common Azimuth Gather by dividing it into 6 azimuth ranges that centered at 0 degree by using 7 inlines and 7 crosslines of rolling window with 15 number of offset bins (every 100 meters from 500 meters to 2000 meters). As shown in Figure 4 , the display from OVT output and COCA gather is different in term of the way it is sorted. The sorting on COCA gather has regularization in the sorting by common offset and then by common azimuth. As the input of OVT gathers have missing traces in particular azimuth and offset, the output of COCA gathers will give empty traces as we keep the number of azimuth range and rolling window parameter low to avoid averaging/borrowing trace process with neighbor traces that located too far away. The missing samples mostly located in the near offset.

Figure 7 shows a COCA gather and AVAZ curve in location 1. The COCA gather shows the event of amplitude analysis is located at $712 \mathrm{~ms}$. In the AVAZ panel, the amplitude on the $\mathrm{Y}$ axis is plotted against the azimuth on the $\mathrm{X}$ axis. Meanwhile, different colors of solid lines and points 


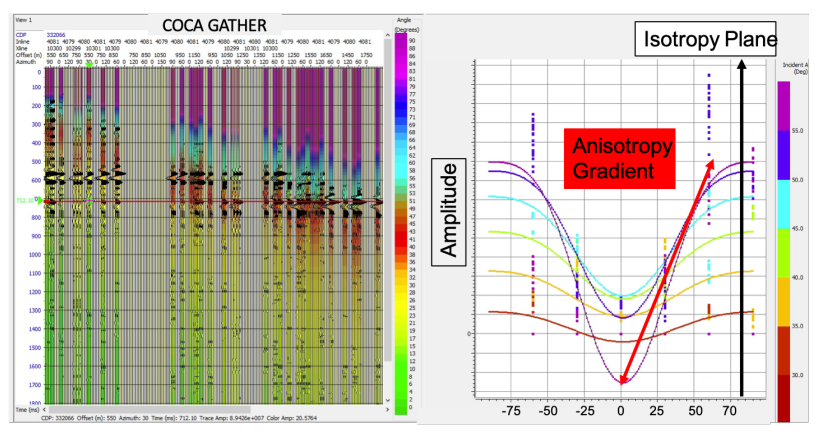

Figure 7. (Left) One CDP of COCA Gather with angle as background color. (Right) AVAZ curve in the shown CDP on the picked horizon (712ms).

indicate the different angle of incident. We can observe that the amplitude changes with azimuth as well as the angle. We can also pick the symmetry plane azimuth, and the isotropy plane azimuth. Based on the aforementioned model, we interpret that the isotropy plane azimuth is parallel to the orientation of the dominant fractures. If we measure the difference in amplitude between the isotropy plane and symmetry plane and layout this information in a map view, we get a map showing the orientation of the isotropy plane in each CDP and the magnitude of the anisotropy (derived from the difference in amplitude between the isotropy plane and the symmetry plane). The map is shown in Figure 8.

The map (Figure 8) is showing the coherence attribute (indicating seismic scale fault) overlaying the anisotropy attribute. There are 2 anisotropy attributes displayed in the figure. First is the vectors indicating the direction of the isotropic plane that later can be interpreted as dominant fracture orientation. This attribute is shown by the orange arrows. The second attribute is the anisotropy magnitude which was measured from the difference between amplitude in the isotropy plane and symmetry plane. The northeast orienting faults might be resulted from the wrenching of the dextral moving Lematang fault. This interpretation is based on the 30-60-degree angle formed between the northeast faults and the Lematang trending fault. Since the Lematang is a wrench fault, the movement of the northeast faults should involve a strike-slip mechanism as well. If this theory holds true, more minor faults of fractures will be generated around the northeast fault and should be angled at 30-60 degree toward the northeast fault, which is exactly shown by the orange arrows. The AVAZ is beneficial for showing the sub-seismic fault or fracture to get a better idea of the structural mechanism in this study area. Eventually, the magnitude of the anisotropy can be an indication of a softer (lower stiffness) fracture. Softer fractures might be open fractures filled with softer material such as hydrocarbon. However, the anisotropy magnitude should not be a direct hydrocarbon indicator. It should be used a dominant fracture indicator. Further investigation should be conducted before concluding to hydrocarbon prospect evaluation.

In the location 2 (Figure 9), the AVAZ curves shows the same pattern as in location 1 . However, the variation of near incident angle and far incident angle in location 2 is not as contrast as in location 1, see Figure 8. In location 2 , the near offset has quite significant variation in term of the amplitude for different azimuth compared to location 1

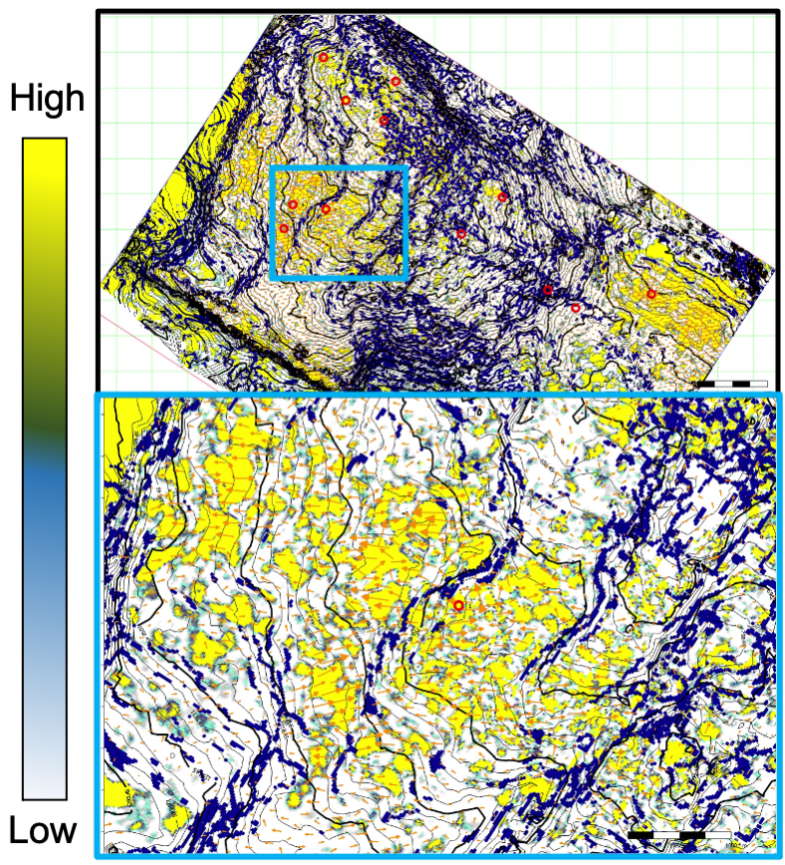

Figure 8. The structural contour overlaid by discontinuity attribute and AVAZ attribute volume as well as the amplitude analysis in location 1. The below picture shows a zoomed display of the blue box from the above picture.

while in the far offset is the other way round. As a result, the anisotropy vector map shows the magnitude is lower due to lower value of anisotropic gradient. However, referring the model in the previous section, this phenomenon could be caused by 2 or more sets of vertical fractures with similar stiffness that hinder the effect of amplitude variation with azimuth. Therefore, location 2 should not be ignored as a prospectively good reservoir.

By looking at the result of AVAZ analysis, it can be said that the local stress causing wellbore breakout might be dominantly affected by the nearby faulting regime rather than regional stress. The fractures and horizontal stress can vary locally and might have different trend than what regional has. This study provides a valuable information of drilling sweet spot in a prospect that have naturally fractured reservoir as its main objective. This interpretation can complement the structural geology analysis.

\section{CONCLUSIONS}

The signatures of seismic anisotropy can be observed in the study area by using rich azimuth 3D seismic data. The anisotropy can be represented by the amplitude variation with azimuth and it can be used to infer the fracture presence, both the intensity and orientation. The result from anisotropy vector maps indicates that the dominant fractures orientation might be different from place to place. The fractures trend can vary locally and even do not follow the dominant direction as also shown at the breakout event of one well in that area. From this study, it can help the orientation of future drilled well in this area that should be crossing the dominant fracture orientation. The detail inter- 


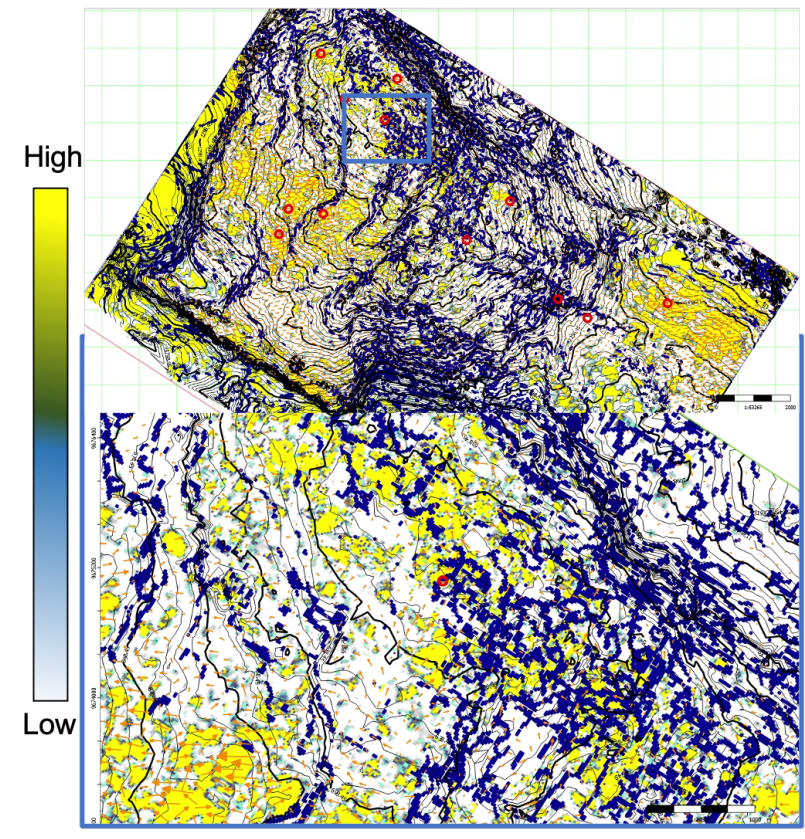

Figure 9. The structural contour overlaid by discontinuity attribute and AVAZ attribute volumes as well as the amplitude analysis in location 2 .

pretation study needed with more detail study of structural interpretation and geomechanics analysis.

\section{ACKNOWLEDGMENTS}

The authors wish to thank the Management of Pertamina EP for their permission to publish this paper.

\section{References}

Daley, P. F., \& Hron, F. (1979). Reflection and transmission coefficients for seismic waves in ellipsoidally anisotropic media. Geophysics, 44, 27-38.

Ikelle, L. T. (1996). Amplitude variations with azimuths (avaz) inversion based on linearized inversion of common azimuth sections. In Seismic anisotropy (p. 601644). SEG.

Nurhasan, A. (2017). 4 d processing and time-lapse azimuthal amplitude analysis using legacy survey for Niobrara reservoir characterization, Wattenberg field, colorado (Unpublished doctoral dissertation). Colorado School of Mines.

Pulunggono, A., Haryo, A., \& Kosuma, C. G. (1992). Pretertiary and tertiary fault systems as a framework of the south Sumatra basin: a study of sar-maps. In Proceedings indonesian petroleum association 21st annual convention.

Rüger, A. (1998). Variation of p-wave reflectivity with offset and azimuth in anisotropic media. Geophysics, $63,935-947$

Rüger, A. (2002). Reflection coefficients and azimuthal avo analysis in anisotropic media (Vol. 10). Society of Exploration Geophysicist.
Thomsen, L. (1993). Weak anisotropic reflections. In J. P. Castagna \& M. Backus (Eds.), Offset-dependent reflectivity - theory and practice of AVO analysis. Society of Exploration Geophysicist.

Tingay, M., Morley, C., King, R., Hillis, R., Coblentz, D., \& Hall, R. (2010). Present Day Stress Field of Southeast Asia. Tectonophysics, 482, 92-104.

Tsvankin, I. (2012). Seismic signature and analysis of reflection data in anisotropic media. Society of Exploration Geophysicist.

Wang, N., Montagner, J.-P., Fichtner, A., \& Capdeville, Y. (2013). Intrinsic versus extrinsic seismic anisotropy: The radial anisotropy in reference earth models. Geophy. Res. Lett., 40, 4284-4288. 